\begin{tabular}{|l|l|l||}
\hline \multicolumn{2}{|c|}{ PublisherInfo } \\
\hline \hline PublisherName & $:$ & Palgrave Macmillan UK \\
\hline \hline PublisherLocation & $:$ & London \\
\hline \hline PublisherImprintName & $:$ & Palgrave Macmillan \\
\hline \hline
\end{tabular}

\title{
Methods explained: Contributions to growth rates under annual chain-linking
}

\begin{tabular}{|l|l|l||}
\hline \multicolumn{2}{|c|}{ ArticleInfo } \\
\hline \hline ArticleDOI & $:$ & $10.1057 /$ palgrave.elmr.1410092 \\
\hline \hline ArticleCategory & $:$ & Feature \\
\hline \hline ArticleFirstPage & $:$ & 53 \\
\hline \hline ArticleLastPage & $:$ & 56 \\
\hline \hline & & RegistrationDate $:$ 2007-6-15 \\
ArticleHistory & $:$ & OnlineDate $\quad$ 2007-6-15 \\
\hline \hline ArticleCopyright & $:$ & Crown copyright2007 \\
\hline \hline
\end{tabular}


Joe Robjohns, ${ }^{\text {Aff1 }}$

Aff1 Office for National Statistics

\section{Demonstrates the stages involved in calculating contributions to growth rates under annual chain-linking and explains their relevance in decomposing growth}

When growth rates of series such as GDP are published by the Office for National Statistics, the contributions of individual components are also often reported. These contributions are a reflection of the importance of each area to the overall total. This article demonstrates the stages involved in calculating thesecontributions and explains their relevance in decomposing growth.

The Full Text of this article can be found on the National Statistics website (http://www.statistics.gov.uk/elmr/06_07/downloads/ELMR06_07Methods.pdf). 